\title{
Creolised Swedish Archaeology
}

\section{Anna Källén}

\begin{abstract}
This is on one level a story of a meeting between Swedish archaeologists, Laotian archaeologists and villagers in the Ban Nabong village in central Laos. It is also about the structures of Swedish archaeology, as revealed in this meeting with alternative views of the past and its material remains. Two central concepts: exotisation and creolisation, are derived from the so-called post-colonial theory to serve as models for describing different attitudes to 'the other' that we meet in any archaeological research. It is argued that a creolised archaeology is worth striving for, because it has the active meeting as a central principle. It produces a multitude of localised knowledges that enrich each other, and is built upon a constant open-ended discussion which prevents us from coming to solutions with the problems of the archaeological praxis.
\end{abstract}

Anna Källén, Department of Archaeology and Ancient History. Uppsala University, S.t Eriks Torg 5, SE-753 10 Uppsala. Sweden.

Key words: creolisation, postcolonial theory, archaeological survey, Laos, Lao Pako, Plain of Jars.

The idea to write this article came to me when I returned home from a fieldwork season in Southeast Asia in early May 2000. Discussions I had with colleagues and fellow PhD students of archaeology in Sweden were mainly about the conditions for doing archaeology in the kind of place where I work, central Laos, a country that has only just begun its tradition of archaeology. Those discussions were, of course, much about Laos, but surprisingly often also about archaeology in general and Swedish archaeology in particular. The Laotian conditions that I encountered in the research project unveiled structures of the archaeological tradition to which I belong as a Swedish archaeologist. Thus Swedish archaeology revealed itself and was open for discussion and questioning.

On the one hand, my aim is to give an example of how the structure of Swedish, or more generally North European, archaeology is made visible as it meets different contexts in Laos. On the other hand, I also want to point to the ambiguous and contradictory nature of any such account, and to the fact that we in archaeology today have no given conceptual apparatus or analytical tools to see and analyse our own praxis. In order to apprehend and conceptualise the structures of my own field, I have borrowed an analytical framework from the so-called post-colonial theory and have extracted from it two concepts: exotisation and creolisation. They will serve as two models, in opposition to each other, for ways to relate to 'the others' that are involved in any archaeological research. I will argue for the need, in international as well as 
national archaeology, to strive for what I call a creolised archaeology, in which an active meeting with 'the other' constitutes the node of archaeological activities. To illustrate my point I will also give examples of what I describe as exotising archaeology, which falls at the other end of the scale towards alienation and dissociation of the object. As the present text moves from theory to concrete examples and further on to my own research project, this argument will prove to be more and more problematic. Is it indeed possible to advocate an archaeology based on meetings, when the meetings can only be described from my position and with my authority as a researcher? I will argue that it is possible, and that it is precisely this ambiguity of the archaeological meeting that makes it worthwhile.

\section{A POST-COLONIAL ARCHAEOLOGY?}

Post-colonial theory needs an introduction in this context. While for decades it has been a significant element in social science and the humanities on the European continent, Australia, and in the United States, it has never had any real effect on academic discussions in Sweden. Perhaps this is due to the somewhat misleading term 'postcolonial', implying that this theory (-ies) would only concern the specific power relations between coloniser and colonised. The underlying argument for such ignorance in Swedish academia seems to be that colonialism and its problems are of no concern to us. Sweden was not a colonising power in strictly political terms in the latest wave of colonisation across the globe. As a consequence, the feeling of collective guilt in relation to earlier colonies that saturates academic discussions in former imperial powers like the United Kingdom and France, is - naturally - lacking in Swedish academia. But Sweden and the other Scandinavian countries are nevertheless part of a West European academic tradition that was built upon a common modern and imperialist view of the world. And not least the historical sciences in general and archaeology in particular are per definition connected with modernity (Rowlands 1994:135; Eriksson 1995:22; cf. also Giddens 1991: 26f, 39).

Also the other part of the term, 'post-colonial', is misleading as to what it is really about, implying that this is something that is after colonialism and thereby separated from it. On the contrary, post-colonial theory is inseparable from colonial theory, in the same way as post-modernist theory is from modernist. It acknowledges structures of power and authority between institutions and other actors that have their origins in colonial systems, but which in some ways have since been reformed and reproduced in new guises. Thus, the use of post-colonial theory must indeed be relevant, not least in Swedish academic encounters with parts of the world that have been directly colonised and de-colonised.

However, while I want to argue that the post-colonial baggage is in many ways a burden, also for Swedish academia, I want to underline that the foremost reason I see post-colonial theory as useful for archaeology, is that it gives an opportunity to see historical power structures in the relations between former imperial powers and colonies. This in turn provides clues as to why certain archaeological results are produced and enhanced in certain situations. Not least is it crucial in order to be able to see and re- 
evaluate our own roles as Scandinavian archaeologists encountering an international arena. Post-colonial theory will thus in this particular case be used not to create a sense of historical guilt for Swedish archaeology, but rather to discuss multi-directional and complex power relations. To see such relations merely in terms of 'goodies' and 'baddies' is, as argued by Stuart Hall (1996:244), far too simple and no longer really arguable. But there must of course also be an element of self-reflection here, since the academic relations between Western Europe and former colonies such as Laos are in many ways unbalanced, and, in the words of Linda Hutcheon, 'those radical [...] challenges are in many ways the luxury of the dominant order which can afford to challenge that which it securely possesses' (1995:131).

The post-colonial theory, which started as a one-way critique of taken-for-granted power relations, directed towards the imperial powers mainly by intellectuals in former colonies and in exile, subsequently developed into a much more complex critical discussion. Alongside the in many ways related discussions on post-modernity, postcolonial theory developed from a critique of the relations between firm categories of strong and weak, bad and good (cf. Chambers 1996:48) into a more nuanced theorycomplex that acknowledges political ambiguity and contradictory power relations in the so-called West as well as in the Third and Fourth Worlds (cf. Hall 1996:245; Chambers 1996:54). In terms of archaeology and cultural heritage management, there are today many different voices that want to be heard, some from parts of the world that have earlier only been talked about as exploited. One example of this is the rising internal interest in saving and restoring buildings and city environments in former colonies in Southeast Asia (Elliot 2000).

\section{EXOTISATION AND CREOLISATION}

Two concepts originating from post-colonial theory are of particular significance to the present topic. The first is that of exotisation. It is closely connected with colonialism, and was introduced as an analytical concept in Edward Said's great, but also rather one-sided, critique in Orientalism (1978), on how the Orient was invented as a concept to make a negative mirror image of Europe. From there it has developed into a more nuanced discussion on representations and images of the 'other'. The exotised object can be described as a stereotyped 'other', possessing qualities that are different and often opposite to those of the subject. The exotisation process leads to a naturalisation of the subject's culture and a confirmation of its group identity. Said (ibid.) and others after him have argued, that on an unconscious level, this is also the purpose of making the 'other' exotic. Exotisation is a way of seeing and representing the 'other' at an analytical distance, without involvement. The act of exotisation simplifies, and the end result is a representation of a stereotyped exotic (Gallini 1996:216). I would argue that much of colonial and neo-colonial international archaeology has used such an exotising perspective.

An alternative way to relate to the 'other' is a creolising perspective. The word creole originates from a specific American colonial situation, and from there the concept of creolisation, as I will employ it here, has developed and been used, mainly by 


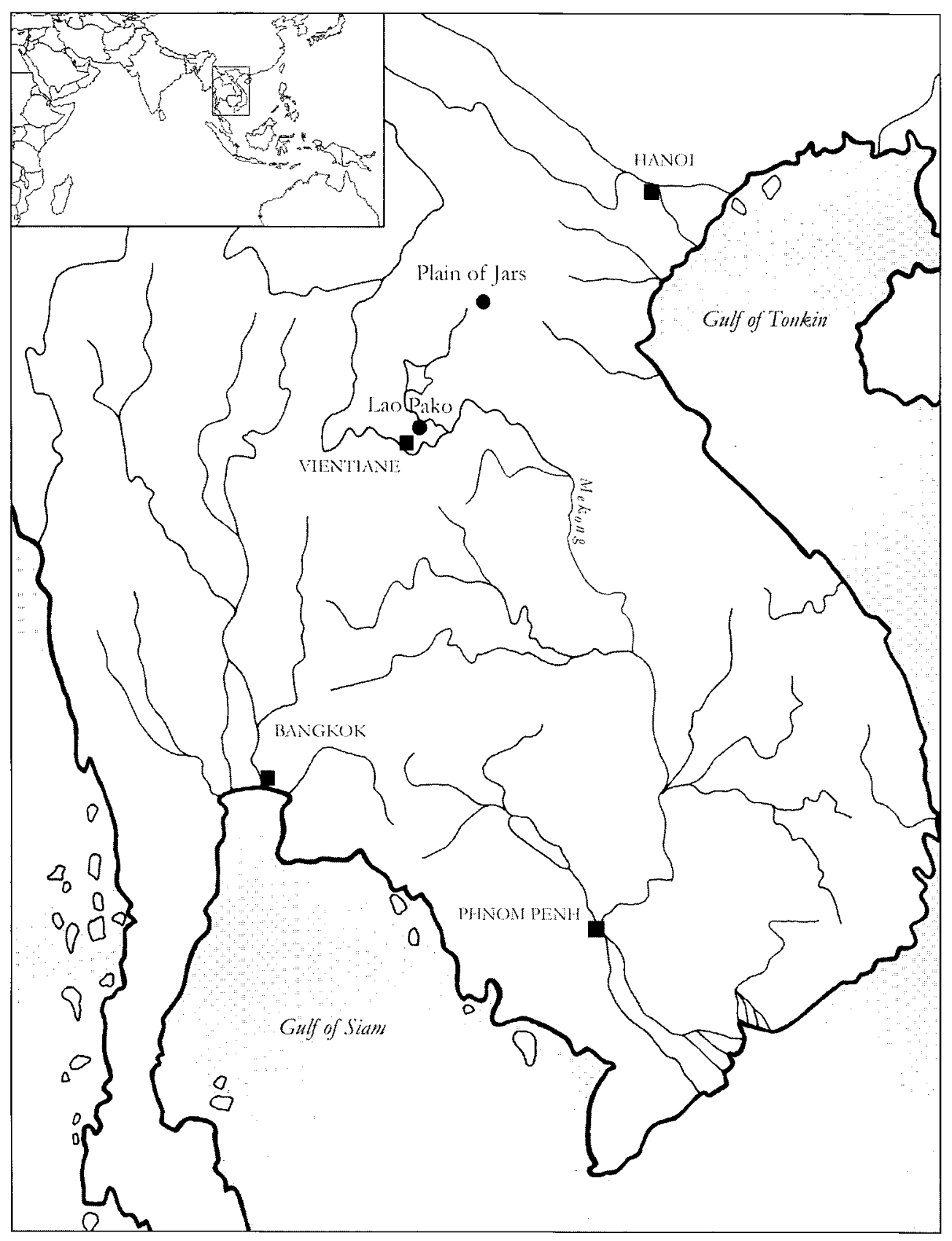

Fig. I. Map of Mainland Southeast Asia with the two major sites mentioned in the tert marked with filled circles. 


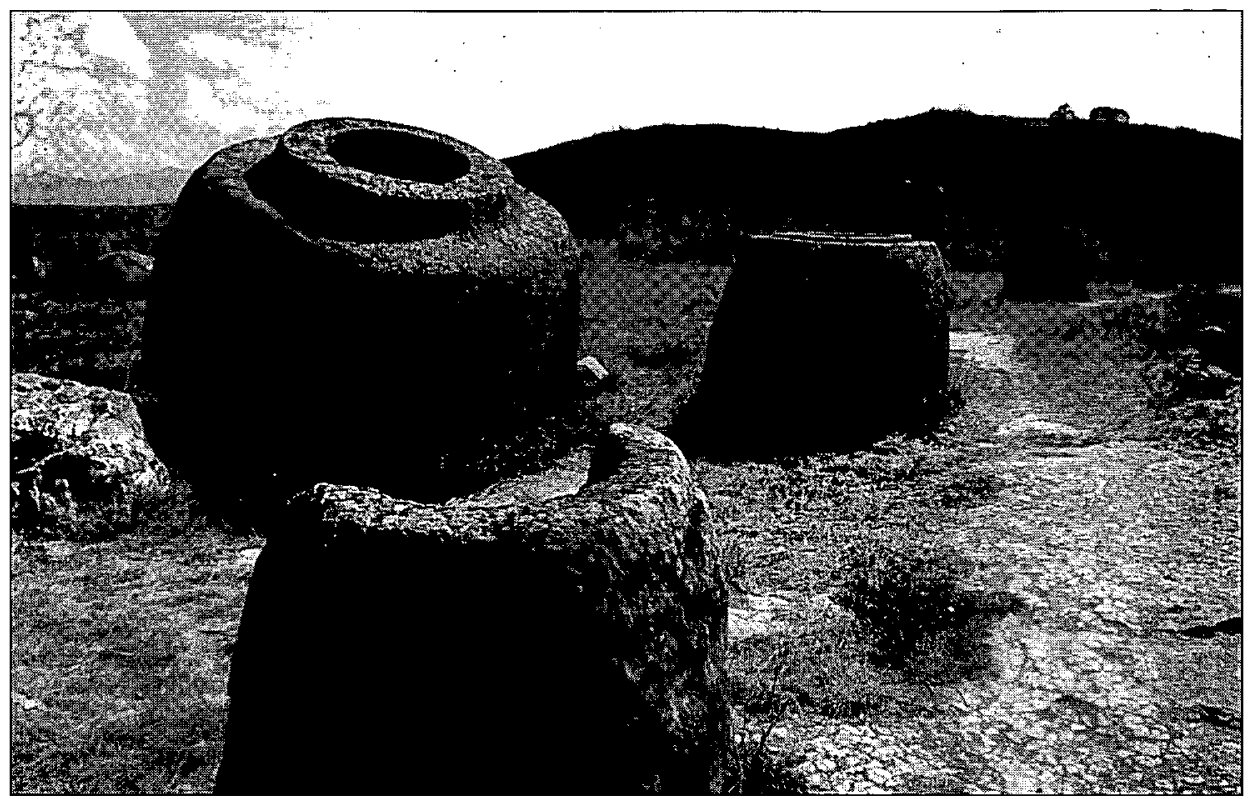

Fig. 2. Stone jar in the Plain of Jars. Xieng Khouang province in Laos. Photo: Anna Karlström.

anthropologists studying modern cultural interactions, as a model for understanding relations between cultures that meet and interact. To quote Ulf Hannerz: ' ...creole cultures - like creole languages - are intrinsically of mixed origin, the confluence of two or more widely separate historical currents which interact in what is basically a center/periphery relationship' (1992: 264). In such a meeting between two or more cultures, different systems of meaning and different cultural expressions meet and interact. What is created - what comes out of this interplay - is something new, something more than simply the sum of the two parts (cf. Eriksen 1995:241, 284; Chambers 1996:49). The process of creolisation implies a direction of power and authority in the cultural meeting, but it is far more complex than a constant flow of cultural influence from the centre to the periphery. Rather, the concept of creolisation allows the voice of the periphery to be heard, and it acknowledges changes in the dominant as well as the dominated (Hannerz 1992: 261-67). This means that a creolising process is an ongoing debate with an open end. The different actors in a meeting will change as a response to influences from other actors, but they do it actively from within, with intact integrity. Thus creolisation is not about merging and cultural homogenisation. On the contrary, it is the creation of something new.

\section{IMAGES OF THE PLAIN OF JARS}

To illustrate the theoretical framework outlined above and connect it to the context in focus here, I will give an example of how four distinct perspectives have created four quite different stories about one and the same place. The place is the so-called Plain of Jars, situated in Xieng Khouang province in Northeast Laos (see figure 2). People from several ethnic groups live today in this area, the majority being Lao though there 
are also smaller communities of Kha and Hmong (Meo)(cf. Chazée 1999). The Plain of Jars is a vast area on a highland plateau with more than 40 sites; some host just a few stone jars, while the largest have almost 400 jars and other monuments (Sayavongkhamdy 1996:11, 2000:105ff). The jars are of varying sizes, up to four metres high, and associated with them are stone discs and other stone monuments. They have been typologically dated to the last centuries BC and the first centuries AD. Pottery, metal artefacts, beads and burnt bones have been found inside and around the jars, which has caused archaeologists to interpret them as connected to human burials. The Plain of Jars also has a recent history and has attracted attention as one of the most tragically war-torn places on earth, with considerable effects from both the French colonial conflicts and the Vietnam War. It is therefore often described as both a highly fascinating place and one of deep tragedy.

No comprehensive study has yet been made on how the local inhabitants perceive these monuments. But in accounts with other focuses, for instance Fred Branfman's Voices from the Plain of Jars (1972) in which people living on the Plain of Jars tell in writing and drawings about their own experiences of the Vietnam War, the jars seem to have no place at all. There are all in all 32 drawings in this book, showing air attacks on elaborated landscapes with houses, people, animals, rivers, mountains and rice fields (figure 3). But there are no depicted stone jars in any of the drawings, even though they seem to be a very tangible part of the physical environment. However, there are legends associated with the jars. Some of them say that the stone jars in ancient times functioned as burial monuments, but most stories are elaborations on the theme that they originate from a time when giants (sometimes equated with the Kha people) populated the plain. They used the jars as containers for food and alcoholic beverages, and led a prosperous life until the Ho people (historically known as an expansive ethnic group originating from south China) invaded the area from the north and destroyed the giants' society (Colani 1935(I):120ff). Today on the Plain of Jars there is a steady and increasing stream of tourists coming to the central town of Phon Savan, and guided tours to the monument sites are arranged with local guides. Tourists are told that the monuments are several thousand years old, and that they were burial monuments of a very prosperous society that once had its centre there.

The French geologist and archaeologist Madeleine Colani

Fig. 3. Drawing by a 16-year-old from the Plain of Jars, showing bomb planes, houses, animals, a river and mountains, but no jars (reproduced from Branfman 1972:67).




worked for three years during the 1930s with the monuments on the Plain of Jars. She was part of the colonial institution École Français d'Extrême Orient, situated in Hanoi and working all over French Indochina. Her work and publications (Colani 1935) from the Plain of Jars have been very influential and appreciated for their scientific quality. Colani excavated in trenches around a number of jars, as well as inside a cave at the central Ban Ang site. She took into account in considerable detail the indigenous mythology concerning the jars and their origins (ibid.(I):120ff), and she agreed with the assumption that there was probably once a prosperous society in this area with its centre to the north-east, yet close to the central monument site (ibid.). The great effort that must have been put into the construction of the monuments is seen as an indicator of a society with quite a large population that was under strong rule (ibid.(II):258). The monuments were interpreted by Colani as burial monuments containing the ashes of bodies that were cremated in the Ban Ang cave (ibid.(II):259). The artefacts that were found around and under the stone monuments were considered mainly for their possibilities to date the monuments and to trace possible relations to other areas around mainland Southeast Asia. The final conclusion is that the jars were constructed in a society on the Plain of Jars between $300 \mathrm{BC}$ and AD 300, which prospered thanks to a junction of important trade routes, mainly for salt, at this particular place. Such trade routes have also been used as an explanation for artefactual links to other areas. The jars would finally have been destroyed during an invasion in which the invaders' purpose was to destroy the old society's link to its ancestors, and thereby undermine its entire foundation (ibid.(I): 120ff).

The present Director General of the Department of Museums and Archaeology at the Laotian Ministry of Information and Culture, Thongsa Sayavongkhamdy, has himself conducted research on the Plain of Jars, as part of his PhD studies. Awaiting the completion of his $\mathrm{PhD}$ thesis, he produced an unpublished booklet containing some preliminary results and interpretations about the Plain of Jars (Sayavongkhamdy 1996). There he described the Plain of Jars as a unique expression of 'the universally known Megalithic Culture', which also includes sites such as Stonehenge, Carnac and the stone sculptures of Easter Island. The jars were interpreted by Sayavongkhamdy as temporary sarcophagi for the deceased and their belongings, until after decomposition when the remains were buried in pits at the foot of the stone jar. This procedure, he suggests, was exclusively for high-ranked persons or the male members of the community. Females and children, on the other hand were cremated and buried in pottery vessels, since the production and transportation of monuments was costly and therefore available only to the cream of society (ibid:11). The society that produced these monuments is said to have been a highly developed one, whose members mastered a number of techniques for subsistence and handicraft (ibid:12). A greater part of the discussion is devoted to a proposed ethnic origin of the society, an argument based on the presence of an anthropomorphic decorative figure found in four different contexts on the Plain of Jars. It is said to represent a mythical 'frog man' that has connections with the present ethnic group Lao, which forms the majority of the present nation state of Laos. If this can be shown to be true, Sayavongkhamdy writes, 'the entering of the 
Lao ethnic group would be pushed back from the $7^{\text {th }}$ century $A D$ to the $7^{\text {th }}$ century $B C$ (1000 years!)' (ibid:11).

Some attention has also been given to the Plain of Jars recently in European magazines, and I will use two such articles to show a more popular (albeit still with scientific pretensions) European view of the Plain of Jars. The first was written by Pierre Rossion for the French magazine Archéologia in 1992. Rossion's article with the title 'Mysterieuse Plaine des Jarres au Laos' describes the Plain of Jars as 'one of the two most fascinating enigmas of the Far East' - the other being Easter Island (Rossion 1992:44, my translation). Rossion's point of departure is that the only serious work carried out on the Plain of Jars was that of Madeleine Colani in the 1930s, and outside of her reports he refers only to other French written accounts from when Laos was part of French Indochina (ibid.). He also gives information about some of the ethnic groups inhabiting the area. The sources of this information, he writes, are legends transmitted from father to son. And '[t] he natives, even the educated, are still convinced that the jars contained seeds, alcohol or rain water. This theory is not valid...'(ibid:46, my translation), because, he argues, should the jars have contained spirituous liquors, it would have been enough for the entire country's population, and that, he says, is absurd (ibid.). He ends the article with an account of the damage done to these monuments during the French and American wars, but he describes recent theft and looting by local inhabitants as a much more serious threat. That, he concludes, is why the Plain of Jars should be protected by UNESCO, and archaeologists from the colonial Indochina institution Ecole Française d'Extrême Orient should continue to do research there (ibid:47).

Flemming Kaul (1998) wrote an article with the title 'Nu vet vi äntligen mer om de mystiska krukorna i Laos' ('Finally we know more about the mysterious jars in Laos', my translation) for the Danish-Swedish magazine Illustrerad Vetenskap. The title refers to an expedition led by the Danish photographer and journalist Freddy Wulf, who went to the Plain of Jars to find new and previously unknown jars. Laos as a whole is here described as one of the most dangerous and isolated places on earth, and Freddy Wulf is portrayed as a heroic character. His search is an adventure involving many risks: with an old Russian cross-country vehicle and by foot, his expedition find their way through mined areas, eventually discovering what seems to be a quarry and manufacturing place for stone jars (Kaul 1998:50f). The Plain of Jars is here called '...one of the world's last great archaeological enigmas', and it is said that '...the stone jars have kept their mystery because Laos has been on the whole closed to archaeologists' (ibid:49, my translation). According to Kaul, there is no internal archaeological activity at all in Laos, and the very small numbers of scientific investigations have all been initiated from the outside: France, USA and Japan. In a small text box he tells about the ethnic group Hmong in the area, who make holes in the soft stone monuments to create nests for their precious fighting cocks. The heading of the text box is 'Old myth destroys stone jars', and it refers to a local story of how the two giants who once made the jars from elephant and buffalo skin, stone, gravel and sugar, had included silver ingots in the bottom of the jars. These are treasures that local inhabitants have 
tried to find by breaking the bottom of the big jars. The people living on the Plain of Jars are thus in several ways identified as the major threat to the preservation of the monuments. Kaul concludes that the protection of this area as a UNESCO World Heritage site, which has been proposed, will demand great efforts, '...not least the enlightenment of the local inhabitants' (ibid:50, my translation).

The four stories about the Plain of Jars, as represented above, are typical of their contexts and can almost be described as stereotypes. Local inhabitants on the Plain of Jars seem to have no strong identity-creating relations to the monuments. They are indeed aware of them, as the jars have a place in mythology where stories about them have an explanatory purpose, but there seem to be no connections between these material remains of the past and the contemporary society in terms of identity links (cf. Rowlands 1994). Such links are instead central in the example of contemporary national archaeology, where the 'frog man' connection with the nationally dominant ethnic group Lao is enhanced. On the other hand, neither the 1930s report by Madeleine Colani nor the contemporary European accounts by Kaul and Rossion show any interest in the possible importance of these monuments to the people of Laos today. Kaul and Rossion instead portray the Plain of Jars as a sort of universal heritage for which European archaeology has a responsibility, and to which local inhabitants are considered the great threat. The local community is in fact seen in a similar manner in both the colonial 1930s version and the contemporary European ones. Local accounts are reproduced as mythologies whose function is to render the stories an exotic touch, an exotisation that results in the readers' dissociation and alienation regarding the Plain of Jars and its present inhabitants. The official Laotian account, on the other hand, shows no interest at all in the accounts of the local inhabitants.

It is also interesting to note the willingness in both the official Laotian archaeology and the contemporary European accounts to portray the Plain of Jars as something extraordinary, which is nevertheless part of a universal phenomenon together with other expressions such as Easter Island. The Laotian account also compares it to megalithic monuments in Europe, while the European accounts deny such comparisons. This reveals a desire from the official Laotian side to be part of, and compared within, the same framework as the global archaeological tradition with its centre in the 'West' (cf. Peterson 1982:125), and the unwillingness on the contemporary European side to allow that.

There is one important conclusion to be drawn from studying Kaul's and Rossion's contemporary archaeological accounts of the Plain of Jars. In line with the discussions in post-colonial theory, that the 'post' in post-colonial must not be mistaken for 'after', we see that it is in many ways a colonial and imperialistic archaeological discourse which these authors, deliberately or not, operate in. I would also argue that their writings are representative for many such accounts in Europe today. Instead of making an effort to involve in a meeting with that which is depicted, there seems to be a striving to have themselves remain completely untouched. In this way, the archaeologist retreat through an act of exotisation to make the Third or Fourth world 'other' into an object to observe, rather than to involve in. 


\section{MEETINGS AT LAO PAKO}

Let us now move on to a specific archaeological investigation that took place during the spring of 2000, at the late prehistoric site of Lao Pako in the Mekong Valley in central Laos. The investigations at the site followed upon a fieldwork campaign four years earlier. That, as well as this present project, was co-directed by the Department of Museums and Archaeology at the Ministry of Information and Culture in Vientiane, and a Swedish university department. Both times the Swedish participants have been Anna Karlström and myself, and the Laotian authorities were in the first campaign represented by the Director General Thongsa Sayavongkhamdy and ethnologist Thonglith Luangkhoth, and in the second by ceramics specialist Bounheuang Bouasisengpaseuth. The involvement from the Laotian side was in both campaigns very much dictated by a strained financial and personnel situation at the Ministry of Information and Culture. Physical difficulties of communication between Sweden and Laos after the fieldwork was completed also affected the reporting. Thus both sides reported on the results from the first fieldwork season separately (see Källén \& Karlström 1999; Källén 2000; Karlström 2000 and Sayavongkhamdy 2000 for more information about the site and the earlier excavation campaign).

In the second fieldwork season, in focus here, the project initiative came from the Swedish side, and the purpose was to extend the very limited knowledge we had about the Lao Pako site from the earlier excavation, to get a setting for the peep-hole we already had. The results were to be incorporated into two ongoing Swedish research projects that focus in different ways on the Lao Pako site. The Laotian side, this time represented by ceramics specialist Mr Bounheuang Bouasisengpaseuth, had expressed an interest in leading further investigations at the Lao Pako site, which could not be accomplished as an internal project. Together we agreed on a five-weeks survey project. Mr Unla Sisongkham, a farmer from the neighbouring village of Ban Nabong, was also employed as an assistant, so all in all there were four members of the team.

When we first planned and started the survey, it was mainly according to Swedish parameters. Our definition of a survey is, naturally, a Swedish kind of archaeological survey, and our Laotian colleagues were initially very modest and followed our initiatives. However, it soon became clear to us that there were several physical difficulties associated with a method of walking in transects, as we had no reliable map material and the vegetation in the major part of the area was too thick to penetrate. It was simply impossible to see any structures or stray finds whatsoever on the ground, due to a thick layer of undergrowth.

As we started to communicate better with our new colleagues, we also started to question our preconceptions of what an archaeological survey is. The more we discussed it, the more unreasonable it seemed, to apply quite uncritically a method that has been developed during three hundred years of surveying in Sweden to a rural area in central Laos, where we only have a vague idea of how people actually relate to the past and its material remains. We agreed with our colleagues that a method based on interviews would probably suit our ends better, and give a more nuanced picture of the prehistoric and historic landscape. The interviews were carried out more or less formally in the 
two closest villages, Ban Phon Kham and Ban Nabong. Most of the time was spent in the villages, walking the village road and visiting people, in some cases several times. This may in some resemble an anthropological study, but there are several differences. Firstly, we never had the time to learn the language well enough to be able to conduct our own interviews, and secondly, we had a very narrow scope; namely that of the landscape of remains from the past.

Our local contact and assistant, Unla Sisongkham, became a key person in the investigation. He was our channel into the village of Ban Nabong, as he was already part of it. We talked a lot, both about our and his view of the landscape that we constantly moved in. He appeared to be interested in how we as European archaeologists saw things, something which he also with great seriousness tried to explain to other people in the village. But more often than not, it all ended in laughter and slight confusion, as we were not able to make the issues quite clear. And the same confusion appeared as we tried to understand how people around Lao Pako today apprehend the landscape and the remains from the past that are part of it. It was obvious that we had quite different ways of apprehending the world around us.

On the archaeological level, this interview-based method resulted in information of two kinds: (i) the location of find spots for artefacts or structures that had been



Fig. 4. Map of the research area around the Nam Num river; with the Lao Pako site and the Ban Nabong village. Sites that were identified in the spring 2000 survey are marked with white triangles. (Original map from 1965. Grid: 1x1 kilometer). 
found by villagers while working the rice fields or digging in the ground for other reasons; and (ii) oral information on the location of old villages and important places from recent history. It was clear early on that it was a few categories of finds or places that were most predominant in the reports we recieved. We identified all in all 21 archaeological sites (figure 4). Of those sites, 17 were identified as historic remains, that is from around AD 800 up to the present, and four were described as prehistoric sites. Twelve of them were identified as complex sites, the rest (9) were find spots of stray finds. Of the finds reported, there are five easily distinguishable categories: architectural constructions (3), pottery (10), metal (2), a combination of metal and pottery (4) and clay pipes (4). Two sites have finds that fall outside of these categories, one with a hoard of ground stone axes, and the other without any visible material remains at all. The architectural constructions were all ruins of old Buddhist temples, or smaller temple-associated buildings. The finds of pottery occurred either in the form of stray potsherds on the ground, or more often as buried stone- or earthenware jars (most often described as burial jars to us, as jar burials are the predominant burial custom even today) that had for some reason been accidentally uncovered. The metal was mainly iron artefacts, and as it often occurred in association with pottery, it was subsequently defined by the villagers as grave goods to jar burials. Clay pipes were only found as stray finds, and they are generally closely associated with temples, or at least with Buddhist rituals that could also be performed elsewhere, for instance in a village.

What do these categories of material culture tell us? What are they representative of? There seems to be a close correspondence between, on the one hand, the objects and structures that we learned of, and, on the other hand, that which is either directly in people's conscious minds because

Fig. 5. Mr To Ting with a complete stoneware jar: found in his back yard (cf. fig. 4. site 16). Photo: Anna Källén.

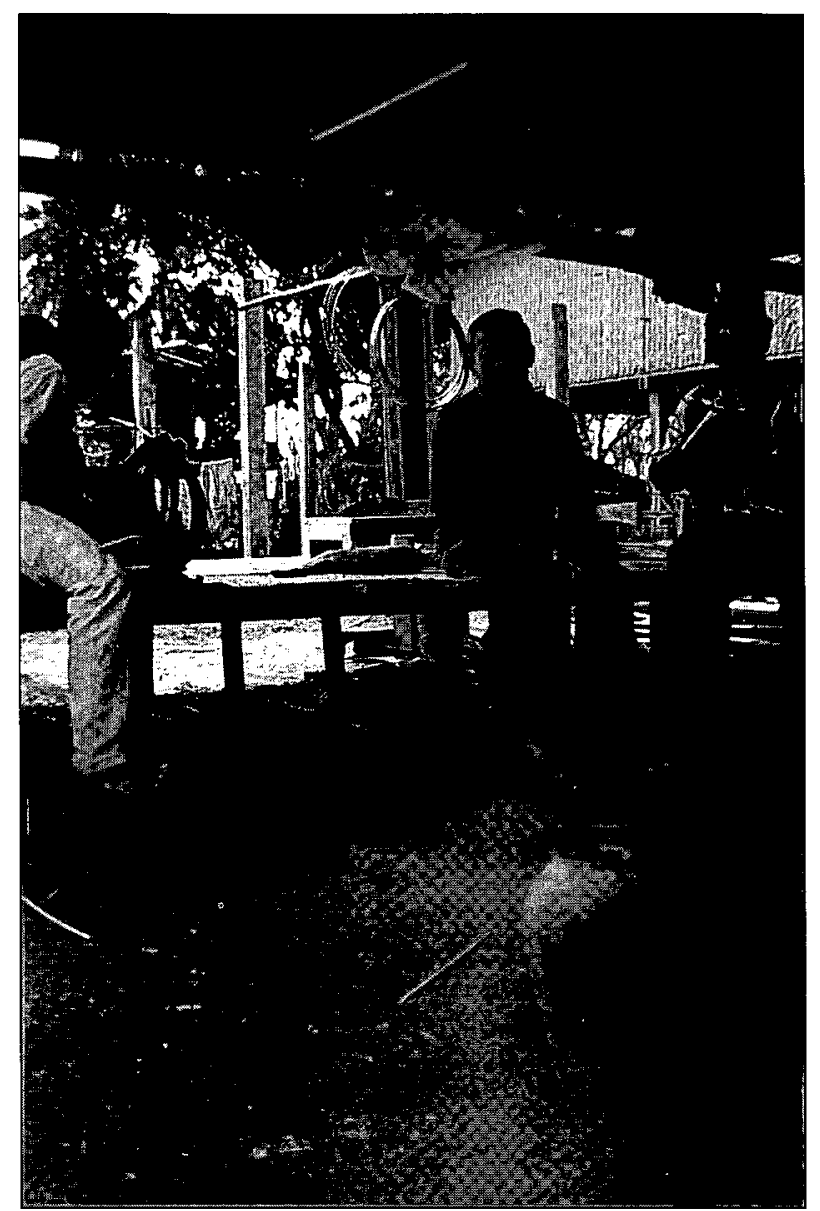


Fig. 6. Mi Unla Sisongkham showing an old bank note with stone axes found by Mr Keo in the background (cf. fig. 4. site 9). Photo: Anna Källén.

it is connected with their daily lives or rituals, or that which we as archaeologists have explicitly expressed an interest in, such as potsherds and stone tools. Regarding pottery, there is in the record also an interesting dominance of stoneware pottery over earthenware, which is not really explicable other than that it possibly reflects a value judgement made by the villagers, who describe stoneware as of much better quality than earthenware pottery.

Perhaps even more interesting are the categories of archaeological finds that fall outside of these parameters, and thus are invisible to the villagers of Ban Nabong. It is,

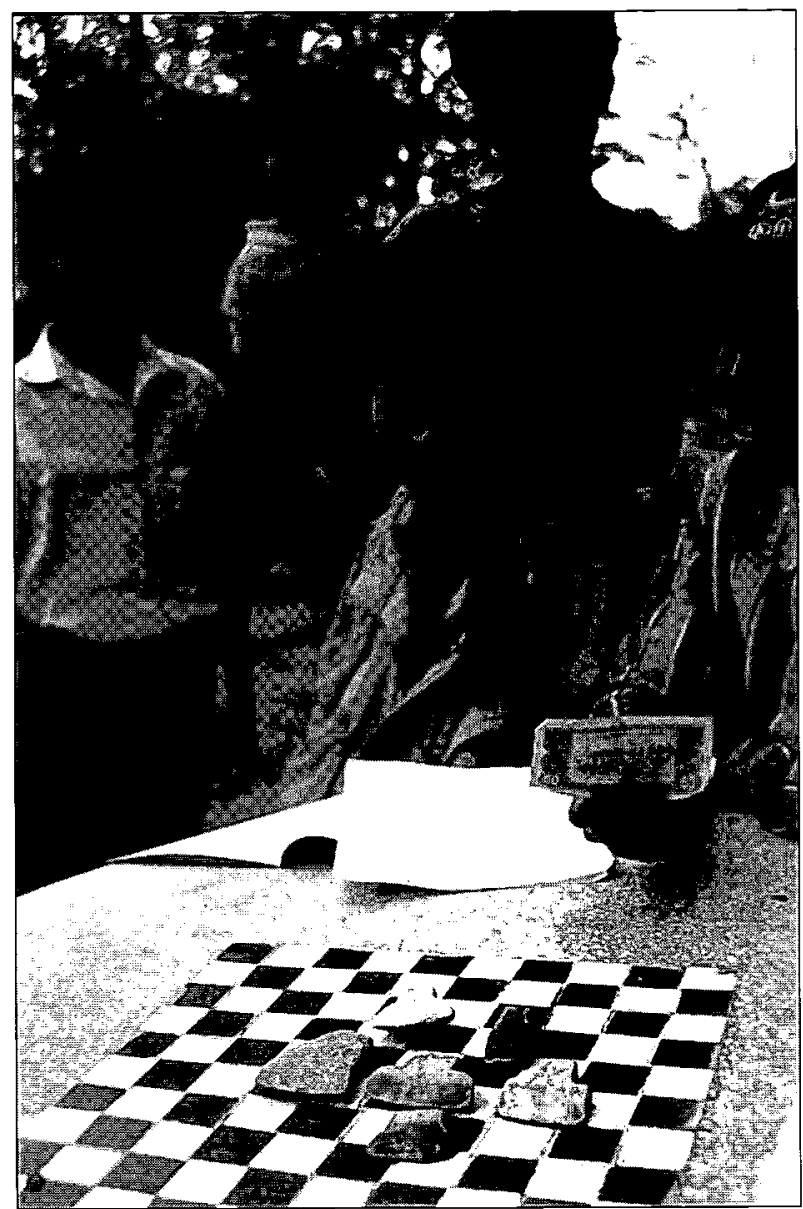
of course, difficult to distinguish such categories, as our archaeological ideas of what to expect are based upon the prehistoric material culture of other distant areas. But an obvious such category that is absent from the records and could be expected to be found to some extent, is earlier prehistoric settlements.

On the other hand, we have the unexpected - that which falls outside of the parameters in a different way. An example of this is seen in figure 6, where Unla Sisongkham is showing a Laotian bank note, a few years old, to the camera in a photo meant to document the contents of a hoard of ground stone axes. Mr Keo in the Ban Nabong village had a couple of years earlier found six small and worn stone axes as he was digging a new well in his back yard. He had kept them in a box in his house together with the old bank note, and he took it out to show us. I still do not know for sure why Unla wanted to show the bank note in the same picture as the Neolithic stone axes, but the only way I can explain it is that he categorised the bank note as old, the same kind of 'old' as the stone axes. Of course both he and Mr Keo are able to conceptualise that the stone axes were buried in the ground before the bank note entered the market, but probably it was not quite clear to them how we in an archaeological survey would 
relate to old things in general. Why would an old bank note be of less interest and value to us than six old axes in the ground? That is indeed a valid question.

On a fundamental level, there were different worlds of ideas that came together during this project season in the Ban Nabong village. The archaeological interests that Anna Karlström and myself represent, depart of course also from us as Swedish women, and as such we have a fundamental view of remains from the past as emotionally value-laden and evoking a sense of identity (cf. Carman 1996). To the people we meet in the Ban Nabong village, things from the past are, described in our terms, seen as no more and no less than just old things, and in some cases synonymous with earth.

The Ban Nabong villagers do, however, relate to remains from the past. Phii, that is spirits or ghosts (cf Condominas 1998:29ff; Tambiah 1970), are often in an informal way connected to remains from the past, such as stoneware jars found in the ground. On an official level there is no such thing as phil, and it is impossible to obtain a firm idea of the spirits' place in the world just by asking questions. But there are numerous stories about strong, healthy men and women that have gone through a lot of trouble to rebury pottery and metal artefacts they had accidentally found in the ground, in order to escape haunting by phii. So there are indeed forces and emotional links in the present that are related to remains from the past. It is, however, not so much about communal identity; rather it is about respect and fear in regard to the deceased people's links to places in the landscape. This does not have the same implication of value as the modern identity-linked view of material remains from the past, but is a different way to value and relate to them.

\section{A CREOLISED ARCHAEOLOGY?}

Let us now move to a higher level of abstraction and discuss these situations of archaeological praxis within the framework of post-colonial theory. The Plain of Jars example gave an indication of the complex relations of power and authority that we operate in, as Swedish archaeologists in an international context. Since scientific archaeology and indeed the scientific sense of history is a modern phenomenon with its origin in the 'West', it is surrounded by a discourse where the origin of power and archaeological authority is in the 'West'. The attractive force of such academic authority should not be underestimated. It is one reason why the official Laotian image of the Plain of Jars is much more in line with national European archaeologies, than the European accounts of the same place are. Thus the official Laotian archaeology is deliberately participating in a discourse that, at this time, puts them one step behind the authority of the 'West'. However, in the same process, the Laotian archaeologists who participate in this discourse, get an authoritative role in relation to their fellow citizens. Thus there are complex relations of power and authority between as well as within the different parties that interact.

As we move to the Lao Pako project in the Ban Nabong village, we have switched focus to a close-up on a small project operated within these structures. More specifically, the focus is on the production of knowledge within this project. It has been argued that different kinds of knowledges were produced and that they enriched each other in the 
process. But what is the nature of the knowledges produced? It is clear that the result was not consensus, but instead that the disrepancies exposed and enhanced the differences in our different ways to relate to the landscape and material remains from the past.

These different knowledges also give concrete examples of how objects and structures that we interpret in archaeology, are sites for different embedded knowledges. Ours as Swedish archaeologists on the one hand and Swedish women on the other. Bounheuang Bouasisengpaseuth's as a Lao man, a ceramics specialist and representative for the Laotian authorities, and Unla Sisongkham as a Lao man, employed in this project and a farmer in the Ban Nabong village. These knowledges in turn are embedded in different social relations, and become explicit and enhanced in different ways depending on the specific social situation.

I would describe these different knowledges as to some degree complementary. But some of them are at one level incommensurate. You cannot as one single person in one particular role truly believe in both the archaeological definition of a stoneware jar, and the Ban Nabong villager's definition of it as a home for phii. This, of course, doesn't mean that you cannot respect a definition that is different from your own and acknowledge that it is the truth in a different context. One single person may very well also apply different definitions as she moves from one role or social situation to another. I suggest that the different knowledges produced can be described in terms of different levels of meaning (cf. Bekaert 1998), all being meaningful to the specific social situations that produce them. However, while this is a perfectly arguable in theory, it is far from unproblematic in practice. The common archaeological praxis of today does not leave much room for such alternative views of the past and its material remains. Basically, it is to write within a discourse that is built on a long tradition of antiquarian strive for interpretative supremacy (Burström 1997), and at the same time recognising alternative views of material remains from the past. We may describe views that are alternative to that of scientific archaeology, but then rather at the level of curiosities, than an actual attempt to involvement. There are no tested conceptual frameworks to apply, so an account of such an actual fieldwork situation becomes quite unorthodox for a scholarly journal of archaeology, as we have seen in the example presented above. It appears that the archaeological theory and its praxis are not corresponding on this matter.

I argue strongly that my aim in doing fieldwork in Laos is to engage in what I would call an archaeological creolisation process (cf. Hannerz 1992:261-67). But the question is to what extent I have succeeded at it. In the Lao Pako project described above, there were clearly meetings taking place on different levels, and there were certainly explicit as well as implicit relations of power and authority between all actors: the Laotian archaeologist, us as Swedish archaeologists, and the Ban Nabong villagers. In the relation between Swedish and Laotian archaeologists, the authority was generally on the Swedish side, as representatives of an active and strong archaeological tradition with funding institutions, following colonial patterns with scientific authority placed in the 'West'. The same relationship was to some extent reproduced in the meeting 
between Swedish and Laotian archaeology on the one hand, and the Ban Nabong villagers on the other. We archaeologists (Swedish and Laotian) were active in seeking meetings for the purpose of our investigations, and we were introducing scientific archaeology to the Ban Nabong villagers, which to them was an abnormal way of thinking about the past.

In my opinion we all changed to some extent through our meetings. Both archaeologists and villagers acquired broader perspectives, with an awareness of alternative ways to perceive the landscape and material remains from the past. And yet, it is far from a cultural homogenisation, so in that respect it can be described as a form of creolisation. On the other hand it can be argued that the result of this creolisation process, the archaeology project to which all actors have now contributed, is still very much situated in the Swedish arena. To go a step further, it can be argued that the Ban Nabong villagers are used here to develop the Swedish debate on archaeology.

Still, I am convinced that a creolised archaeology is worth striving for. The creolising perspective acknowledges the periphery's voice, while it also recognises that it in some way dominated. It is no longer really feasible for archaeologists from the 'West' to come in and teach local archaeologists how to address different issues. But it is also important to recognise the relations of power and the attractive forces of different kinds of authority, that are affecting centres as well as peripheries. Such a perspective thus gives an opportunity to better understand the localised, or creolised, knowledges we are producing.

\section{CONCLUSION}

I have tried here to sketch a theoretical framework in which it is possible to conceptualise an archaeological meeting such as that within the ongoing Lao Pako project in Laos. With post-colonial theory we are forced to see ourselves as pawns in the game, to recognise that we, as well as the people of Laos, are sensitive to and shaped by the political and social structures that we, and thus also the archaeology we create are part of. The use of post-colonial theory in this case has also revealed ambiguities, and the theory has been shown to be far from unproblematic in practice. As we acknowledge power structures that we ourselves are part of in our archaeological praxis, we must also recognise that any account will be from our specific point of view and must be seen as an expression of our authority as archaeologists or researchers. It will inevitably be my voice that is heard in a forum like this, not the Laotian archaeologist's nor that of the Laotian villager. This in turn implies a constant risk of misrepresentation of other actors' views and intentions, and inevitably an exotisation of the Laotian objects, no matter how great the willingness is for creolisation. Some readers may have been disappointed in my inability to come to solutions with such contradictions. But my aim is partly to bring out this inability. As I have argued elsewhere, archaeology is ambiguous and difficult per definition, and should so be. To suggest a solution would be to make a problem out of that which is inevitably a part of the archaeological discipline (cf. Källén 1999:13). Instead archaeology should be acknowledged as a dynamic activity, and its praxis - as well as its theory - must include a willingness to meet and to be 
touched and changed, actively from within. Such meetings are also a way to further develop discussions on important issues of archaeology, such as how the past and its material remains are used and valued.

\section{ACKNOWLEDGEMENTS}

I am grateful to Patrik Nordström for offering and discussing ideas on which the argument of this article is based. My warmest thanks also to Elisabet Regner and Michael Rowlands, whose comments and critique of earlier drafts meant a lot to the final version of the text, although they may not agree with everything in it. Finally I wish to thank Anna Karlström for being a great part of it all, and for borrowing her beautiful photo from the Plain of Jars.

\section{English revised by Laura Wrang.}

\section{REFERENCES}

Bekaert, S. 1998. Multiple levels of meaning and the tension of consciousness - How to interpret iron technology in Bantu Africa. Archaeological Dialogues 1998-1. Pp. 6-29.

Branfman, F. (Ed). 1972. Röster frìn Krukslätten Prisma. Stockholm.

Burström, M. 1997. Disciplinating the Past. The Antiquarian Striving for Interpretative Supremacy. Current Swedish Archaeology: Vol. 5, 1997. Pp. 41-47.

Carman, J. 1996. Valuing Ancient Things: Archaeology and Law. Leicester University Press.

Chambers, I. 1996. Signs of silence, lines of listening. In: I. Chambers \& L. Curti (Eds). The Post-Colonial Question. Common skies, divided horizons. Pp. 47-62. Routledge. London.

Chazée, L. 1999. The Peoples of Laos. Rural and Ethnic Diversities. White Lotus Press. Bangkok.

Colani, M. 1935. Mégalithes du Haut-Laos (l-ll) Publications d'Ecole Francaise d'Extrême Orient XXVXXVI. Paris.

Condominas, G. 1998. Le Bouddhisme au Village. École Française d'Extrême Orient, Éditions des Cahiers de France, Ambassade de France. Vientiane.

Elliott, D. 2000. Saving the Future Past. Newsweek January 17, 2000. Pp. 38-44.

Eriksen, T. H. 1995. Small Places, Large Issues. Pluto Press, London.

Evans, G. 1999. What is Lao Culture and Society? In: G. Evans (Ed). Lao Culture and Society. Pp. I-34. Silkworm Books. Chiang Mai.

Giddens, A. 1991. Modernitet och självidentitet. Självet och samhället i den senmoderna epoken. Daidalos. Gothenburg.

Gallini, C. 1996. Mass exoticisms. In: I. Chambers \& L. Curti (Eds). The Post-Colonial Question, Conmon skies, divided horizons. Pp. 212-220. Routledge. London.

Hannerz, U. 1992. Cultural complexity : studies in the social organization of Meaning. Columbia University Press. New York.

Hall, S. 1996. When was "the post-colonial'? Thinking at the limit. In: I. Chambers \& L. Curti (Eds). The Post-Colonial Question. Common skies, divided horizons. Pp. 242-260. Routledge. London.

Hutcheon, L. 1995. Circling the Downspout of Empire. In: B. Ashcroft, G. Griffiths \& H. Tiffin (Eds). The Post-colonial Studies Reader: Pp. 130-35. Routledge. London.

Källén, A. 1999. The Viking Saga and the Dông S'on Myth - a Story of Prehistories. In: P. Nordström \& M. Svedin (Eds). Aktuell Aikeologi VIl. Stockholm Archaeological Reports No 36. Pp. 5-15. Stockholm. 
-2000. Lao Pako in the Late Prehistory of Mainland Southeast Asia. In: D. Bulbeck \& P. Bellwood (Eds). Bulletin of the Indo-Pacific Prehistory Association (BIPPA) No 19, Vol 3. Pp. 93-100.

Källén, A. \& Karlström A. 1999. Lao Pako, a Late Prehistoric Site on the Nâm Ngum River in Laos. BAR International Series No 777. Archaeopress. Oxford.

Karlström, A. 2000. Lao Pako, an Iron Age site on the Nâm Ngum river in Laos', In: D. Bulbeck \& P. Bellwood (Eds). Bulletin of the Indo-Pacific Prehistory Association (BIPPA) No 19, Vol 3.

Kaul, F. 1998. Nu vet vi äntligen mer om de mystiska krukorna i Laos ('Finally we know more about the mysterious jars in Laos'). Illustrerad vetenskap No 14/98. Pp. 48-51.

Peterson, W. 1982. Colonialism, Culture History and Southeast Asian Prehistory. Asian Perspectives, Vol XXV No 1. Pp. 123-132.

Rossion, P. 1992. Mysterieuse Plaine des Jarres au Laos. Archéologia No279:1992. Pp. 42-47.

Rowlands, M. 1994. The politics of identity in archaeology. In: G. C. Bond \& A. Gilliam (Eds). Social Construction of the Past: Representation as Power: Pp. 129-143. Routledge. London.

- 1998. The Archaeology of Colonialism. In: K. Kristiansen \& M. Rowlands Social Transformations in Archaeology - Global and Local Perspectives. Chapter 12. Routledge. London.

Said, E. W. 1978. Orientalism. Routledge \& Kegan Paul. London.

Sayavongkhamdy, T. 1996. Prehistory in Laos. Unpublished booklet from the Ministry of Information and Culture, Department of Museums and Archaeology, Lao P.D.R.

- 2000 Recent Archaeological Research in Laos. In: D. Bulbeck \& P. Bellwood (Eds). Bulletin of the Indo-Pacific Prehistory Association (BIPPA) No 19, Vol 3.

Tambiah, S. J. 1970. Buddhism and the Spirit Cults in North-East Thailand. Cambridge Studies in Social Anthropology. Cambridge University Press. Cambridge. 